\title{
PENGARUH PENERAPAN MODEL PEMBELAJARAN THINK TALK WRITE TERHADAP KEMAMPUAN PEMAHAMAN KONSEP MATEMATIS SISWA KELAS VIII MADRASAH TSANAWIYAH AL-IHSAN
}

\author{
Helma Mustika ${ }^{1}$,Muslikatun Hasanah ${ }^{2}$ \\ ${ }^{1,2}$ STKIP Insan Madani Airmolek \\ muslikatun41@gmail.com¹, helmamustika@ymail.com²
}

\begin{abstract}
This study began with many students having low concept comprehension skills. This can be seen from the learning process that there are still many students who are less active, and there are still many students who still get grades below the KKM. the purpose of this study was to determine the ability to understand students 'mathematical concepts using the Think Talk Write learning model better than students' ability to understand mathematical concepts using conventional learning models in class VIII MTs Al-Ihsan. The type of this research is experimental, the design is Quasi Experimental, with Randomized Subjects Posstest Only Control Group Design. The sampling technique in this study is cluster random sampling, where class VIII. 3 was chosen as the experimental class and class VIII.5 as the control class. Data collection techniques through concept understanding tests, then data analysis techniques used are inferential statistical analysis using the " $t$ " test (Independent Sample $t$ Test). Based on the results of research testing the hypothesis of this study obtained $t$ count $=2.061>t$ table $=$ 1.999. This means that the ability to understand mathematical concepts of students using Think Talk Write learning models is better than the ability to understand mathematical concepts of students using conventional learning models in class VIII MTs Al-Ihsan
\end{abstract}

Keywords: Think Talk Write, Understanding Concepts

\section{PENDAHULUAN}

Matematika adalah ilmu pasti yang memiliki peranan penting dalam dunia pendidikan. Hal ini dapat dilihat dari pelajaran matematika di sekolah lebih banyak dibandingkan dengan pelajaran yang lain. Oleh karena itu, pelajaran matematika diberikan di semua jenjang pendidikan, mulai dari sekolah dasar hingga perguruan tinggi. Akan tetapi, masih banyak siswa yang beranggapan bahwa matematika adalah mata pelajaran yang sulit.

Berdasarkan observasi dan wawancara dengan guru mata pelajaran matematika di MTs Al-Ihsan Buluh Rampai pada tanggal 15 Juli - 18 Juli 2019, diperoleh bahwa pemahaman konsep siswa dalam pembelajaran matematika masih belum memuaskan, ini terbukti dari hasil belajar siswa belum mencapai Kriteria Ketuntasan Minimum (KKM) yaitu 65. Kemudian sebagian besar siswa kurang aktif dalam kegiatan pembelajaran, mengalami kesulitan dalam mengerjakan soal yang sedikit berbeda dari contoh yang diberikan serta kesulitan dalam memilih konsep yang benar dalam menyelesaikan masalahmasalah tersebut. Oleh karena itu dalam proses pembelajaran, guru harus bisa meyakinkan siswa bahwa matematika itu tidak sesulit yang dibayangkan.

Menurut Istarani (2014) model pembelajaran adalah seluruh rangkaian penyampaian materi ajar yang meliputi segala aspek sebelum, sedang dan sesudah pembelajaan yang dilakukan guru serta segala fasilitas yang terkait yang digunakan secara langsung atau tidak langsung dalam proses belajar mengajar.

Menurut Ali (2014) Model pembelajaran adalah suatu rencana atau pola yang digunakan dalam menyusun kurikulum, mengatur materi peserta didik, dan memberi petunjuk kepada pengajar di kelas dalam setting pengajaran atau setting 
lainnya. Dari definisi-definisi tersebut dapat disimpulkan bahwa model pembelajaran adalah suatu rencana atau pola yang digunakan oleh guru sebagai pedoman dalam melaksanakan kegiatan pembelajaran.

Model pembelajaran matematika adalah kerangka kerja konseptual tentang pembelajaran matematika (Ali, 2014). Model pembelajaran matematika tidak lepas dari sistem pembelajaran yang mempunyai komponen-komponen seperti tujuan, pengalaman belajar, pengorganisasian pengalaman belajar dan merupakan komponen pokok dalam sistem kurikulum dan pengajaran.

Model pembelajaran TTW pertama kali diperkenalkan oleh Huinker dan Laughlin pada tahun 1996. Model pembelajaran TTW berlandaskan pada pembelajaran kontruktivistik yang diterapkan melalui kegiatan berpikir, berbicara, dan menulis. Menurut Isrok'atun (2018) inti dari model pembelajaran TTW adalah suatu desain pembelajaran kontruktivistik melalui kegiatan komunikasi diri sendiri, antarsiswa, dan guru yang mendorong siswa untuk berpikir, berbicara, menyampaikan pendapat, serta menuliskan hasilnya.

Dalam pembelajaran matematika, model pembelajaran TTW diterapkan melalui tiga kemampuan matematis yakni berpikir matematis, berbicara matematis, dan menulis matematis.

Model pembelajaran TTW memiliki beberapa karakteristik, diantaranya yaitu :

1) Siswa berpartisipasi langsung dalam pembelajaran.

Dalam model ini siswa menjadi subjek dalam proses pembelajaran. Siswa berinteraksi dengan diri mereka sendiri dalam aktivitas berpikir. Selanjutnya, siswa berinteraksi dengan teman dalam mengungkapkan pendapatnya selama proses diskusi kelompok kecil. Selain itu, siswa berkinteraksi dengan guru dalam mengarahkan penulisan laporan hasil presentasi kelompok.

2) Setiap siswa secara aktif melakukan eksplorasi suatu konsep.
Yaitu kegiatan belajar diawali dengan proses berpikir (think), dimana setiap siswa berpikir mengenai suatu fenomena yang disajikan oleh guru baik dalam bentuk gambar ataupun suatu bacaan. Siswa mengungkapkan pendapat berdasarkan pemikirannya untuk didiskusikan dengan siswa lain dalam mencari dan menemukan suatu konsep materi.

3) Model pembelajaran TTW dibangun oleh kemampuan berpikir, berbicara, dan menulis.

Kegiatan pembelajaran didasari pada aktivitas siswa dalam berpikir (think), berbicara (talk), dan menulis (write) untuk mengonstruksi materi atau suatu konsep ilmu. Pembelajaran ini didasari pada keterampilan berpikir, berbicara, dan menulis.

Langkah-Langkah dalam model pembelajaran TTW yaitu (Shoimin, 2014):

1) Guru membagi siswa dalam kelompok kecil (3-5 siswa).

2) Guru membagikan LKS yang memuat soal yang harus dikerjakan oleh siswa serta petunjuk pelaksanaannya.

3) Peserta didik membaca masalah yang ada dalam LKS dan membuat catatan kecil secara individu tentang apa yang diketahui dan tidak diketahui dalam masalah tersebut.

4) Siswa berinteraksi dan berkolaborasi dengan teman satu grup untuk membahas isi catatan dari hasil catatan (talk).

5) Dari hasil diskusi, peserta didik secara individu merumuskan pengetahuan berupa jawaban atas soal (berisi landasan dan keterkaitan konsep, metode, dan solusi) dalam bentuk tulisan (write) dengan bahasannya sendiri.

1) Kemudian perwakilan kelompok menyajikan hasil diskusi kelompok, sedangkan kelompok lain diminta memberikan tanggapan.

2) Kegiatan akhir pembelajaran adalah membuat refleksi dan kesimpulan atas materi yang dipelajari. 
Sebelum itu dipilih beberapa atau satu orang peserta didik sebagai perwakilan kelompok untuk menyajikan jawabannya, sedangkan kelompok lain menanggapi.

Dalam penelitian ini kemampuan pemahaman konsep matematis akan diukur dengan menggunakan indikator diantaranya yaitu (Kesumawati: 2008)

1) Menyatakan ulang sebuah konsep.

2) Mengklasifikasikan objek-objek menurut sifat-sifat tertentu sesuai dengan konsepnya.

3) Memberi contoh dan bukan contoh dari suatu konsep.

4) Menyajikan konsep dalam berbagai bentuk representasi matematis.

5) Mengembangkan syarat perlu atau syarat cukup suatu konsep.

6) Menggunakan, memanfaatkan, dan memilih prosedur atau operasi tertentu dan,

7) Mengaplikasikan konsep atau algoritma pemecahan masalah.

\section{METODE}

Metode penelitian yang digunakan dalam penelitian ini adalah Quasi Experimental Design, dengan teknik pengambilan sampel yaitu cluster random sampling. Kemudian untuk teknik pengumpulan data menggunakan teknik tes. Tes dilakukan sesudah materi diajarkan, guna untuk mengetahui kemampuan pemahaman konsep siswa pada kelas sampel dengan menerapkan model pembelajaran Think Talk Write. Tes berbentuk soal uraian yang terdiri dari 4 soal dengan materi pola bilangan.

Teknik analisis data dalam penelitian ini bertujuan untuk menguji kebenaran hipotesis yang diajukan dalam penelitian. Teknik analisis data yang digunakan dalam penelitian ini adalah analisis statistika inferensial. Analisis ini dilakukan terhadap data hasil posttes sesudah penelitian. Karena data berasal dari sampel yang saling bebas maka uji statitik yang digunakan terhadap dua sampel yang saling bebas yaitu dengan menggunakan uji " $\mathrm{t}$ " (Independent Sample t Test).
Secara umum langkah pengujian sampel yang saling bebas yaitu sebagai berikut:

1) Mencari nilai rata-rata dari kedua kelompok.

2) Merumuskan hipotesis nol dan hipotesis alternatifnya.

3) Menguji normalitas sebaran data kedua kelompok sampel.

Uji normalitas bertujuan untuk melihat apakah sampel berasal dari populasi yang terdistribusi normal atau tidak. Uji normalitas menggunakan software SPSS 22 Jika kedua kelompok sampel berdistribusi normal, maka dilanjutkan dengan menguji homogenitas kedua varians.

4) Sebelum dilakukan uji beda dua ratarata maka dilakukan uji $\mathrm{F}$ (uji homogenitas), artinya jika varian sama maka uji t menggunakan nilai Equal Variance Assumed (diasumsikan varian sama) dan jika varian berbeda menggunakan nilai Equal Variance Not Assumed ( diasumsikan varian berbeda).

5) Jika menghasilkan varians yang homogen, maka langsung dilakukan uji hipotesis secara statistik dengan uji t. Uji Independent Samples T-Test atau uji $\mathrm{t}$ pada penelitian ini dilakukan dengan bantuan software SPSS.

\section{HASIL PENELITIAN DAN PEMBAHASAN}

Jumlah pertemuan yang dilakukan peneliti dalam kelas sampel adalah sebanyak empat pertemuan setiap kelasnya. Dimana pada kelas eksperimen empat pertemuan menggunakan model pembelajaran Think Talk Write, dan empat pertemuan pada kelas kontrol dengan menggunakan model konvensional. Perbedaan pemahaman konsep matematika siswa dapat dilihat melalui hasil analisis rata-rata tes setiap butir soal yang diberikan. Untuk lebih jelasnya pemahaman konsep antara siswa kelas eksperimen dan siswa kelas kontrol dapat dilihat pada gambar berikut. 


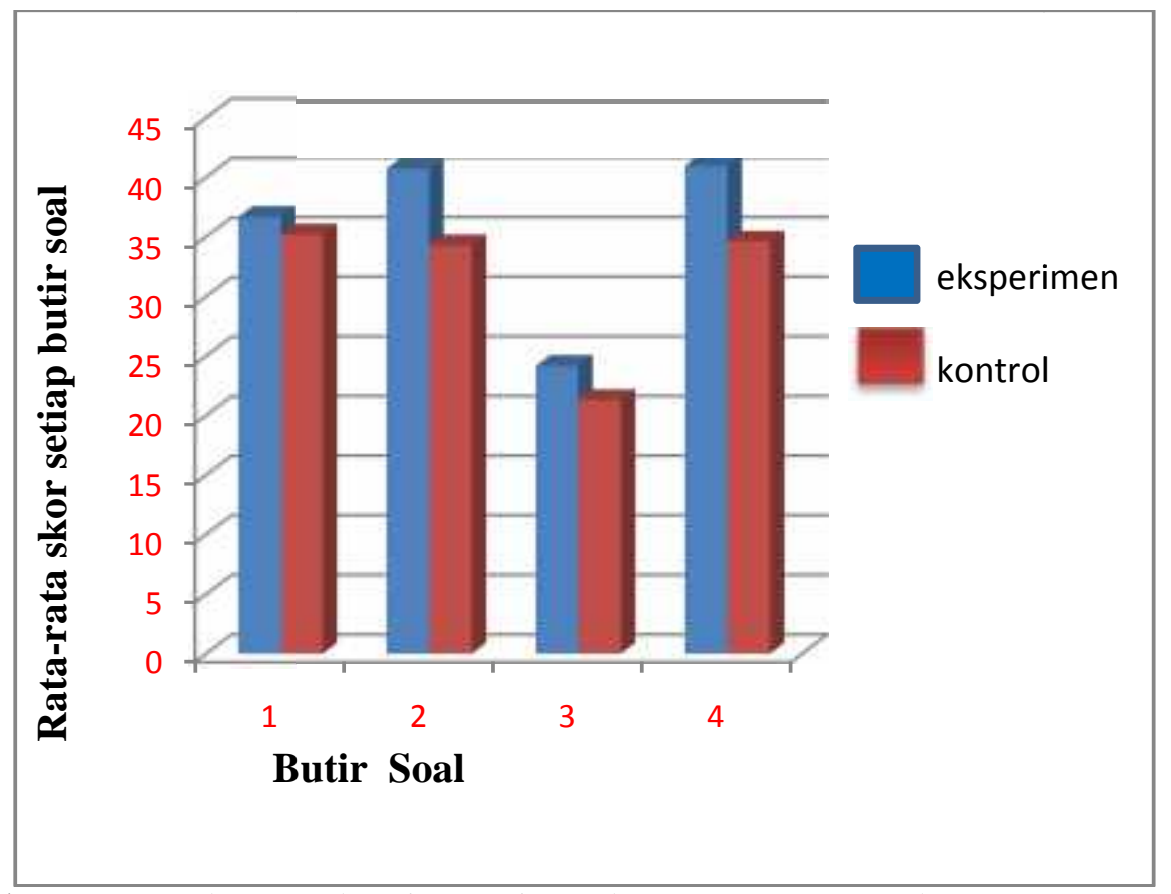

Gambar 1. Rata-rata Skor Total Setiap Butir Soal Kemampuan Pemahaman Konsep Matematis Siswa Kelas Sampel

Pada gambar di atas, dapat dilihat bahwa rata-rata skor total setiap butir soal untuk kelas eksperimen lebih tinggi daripada ratarata skor total setiap butir soal kelas kontrol.

Tes kemampuan pemahaman konsep diberikan untuk mengukur kemampuan pemahaman konsep matematika siswa pada materi pola bilangan setelah dilakukan pembelajaran dengan model pembelajaran TTW pada kelompok eksperimen dan konvensional pada kelompok kontrol. Setelah diberikan perlakuan yang berbeda, kemudian kedua kelas diberi posttest untuk mengukur kemampuan pemahaman konsep. Hasil posttest ini dijadikan data untuk menguji hipotesis dalam penelitian. Sebelum hipotesis dilakuan terlebih dahulu dilakukan uji normalitas dan homogenitas.

Uji normalitas pada penelitian dilakukan dengan menggunakan software SPSS 22, yang bertujuan untuk melihat apakah sampel berdistribusi normal atau tidak. Uji ini dilakukan kepada kedua kelas sampel yaitu kelas eksperimen dan kelas kontrol. Hasil perhitungan uji normalitas kedua sampel dapat dilihat pada Tabel 1 berikut.

Tabel 1. Hasil Perhitungan Uji Normalitas Kelas Sampel

\begin{tabular}{|c|r|r|}
\hline Sampel & Nilai Sig. & Keterangan \\
\hline Eksperimen & 0,200 & Normal \\
\hline Kontrol & 0,074 & Normal \\
\hline
\end{tabular}

Dari Tabel 1 terlihat bahwa nilai signifikan pada kelas eksperimen adalah 0,200 dan nilai signifikan pada kelas kontrol adalah 0,074. Dimana nilai signifikan pada kedua kelas lebih besar dari 0,05, sehingga $\mathrm{H}_{0}$ diterima. Dengan demikian, dapat disimpulkan bahwa kedua kelas sampel berdistribusi normal.

Selain data berasal dari sampel berdistribusi normal, harus diperhatikan juga apakah kedua sampel homogen atau tidak. Oleh karena itu dilakukan uji Homogenitas dengan menggunakan software SPSS.

Setelah sampel berdistribusi normal dan memiliki variansi yang sama, maka dilakukan uji hipotesis dengan menggunakan (Uji-t) Independent Sample T-Test dengan bantuan software SPSS 22 . Berdasarkan hasil uji $t$, didapat $t_{\text {hitung }}>t_{\text {tabel }}$ 
atau 2,061 >-1,998, maka hipotesis nol $\left(\mathrm{H}_{0)}\right.$ ditolak dan hipotesis kerja $\left(\mathrm{H}_{\mathrm{a}}\right.$ diterima. Jadi dapat disimpulkan bahwa "Ada pengaruh yang signifikan antara penggunaan model pembelajaran Think Talk Write terhadap kemampuan pemahaman konsep matematis siswa kelas VIII MTs Al Ihsan Buluh Rampai Kecamatan Seberida".

Berdasarkan hasil penelitian yang telah dilakukan ternyata kemampuan pemahaman konsep matematika siswa yang di ajar dengan model pembelajaran Think Talk Write lebih baik daripada kemampuan pemahaman konsep matematika siswa yang diajar dengan pembelajaran konvensional. Hal ini dikarenakan pada tahap penggunaan model pembelajaran Think Talk Write siswa dilatih untuk menyajikan konsep dalam berbagai bentuk representasi matematika, menggunakan dan memanfaatkan serta memilih prosedur atau evaluasi tertentu dan mengaplikasikan konsep atau alogaritma pada pemecahan masalah.

Berikut ini disajikan deskripsi dari bentuk-bentuk indikator kemampuan pemahaman konsep matematika siswa pada kelas eksperimen dan kelas kontrol yang diperoleh dari hasil tes kemampuan pemahaman konsep matematika siswa.

1) Menyajikan konsep dalam berbagai bentuk representasi matematika.

Kemampuan menyajikan konsep dalam berbagai bentuk representasi matematika pada kelas sampel ditinjau dari hasil tes kemampuan menyajikan konsep dalam berbagai bentuk representasi matematika siswa pada soal nomor 2. Pada soal nomor 2 , siswa disajikan gambar yang berkaitan dengan pola bilangan, dan siswa diminta untuk menentukan pola bilangan yang terbentuk berdasarkan gambar tersebut. Berikut ini contoh jawaban siswa di kelas eksperimen dan kontrol untuk soal nomor 2.

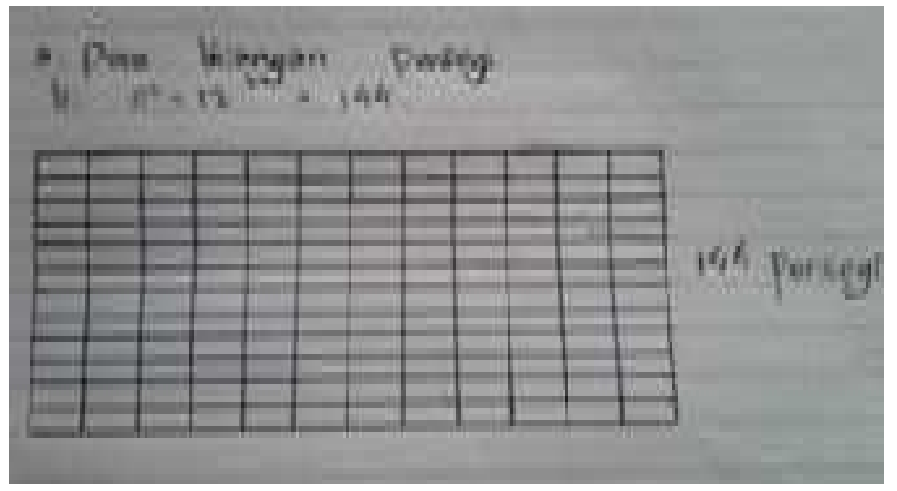

Gambar 2. Jawaban siswa kelas eksperimen pada soal nomor 2

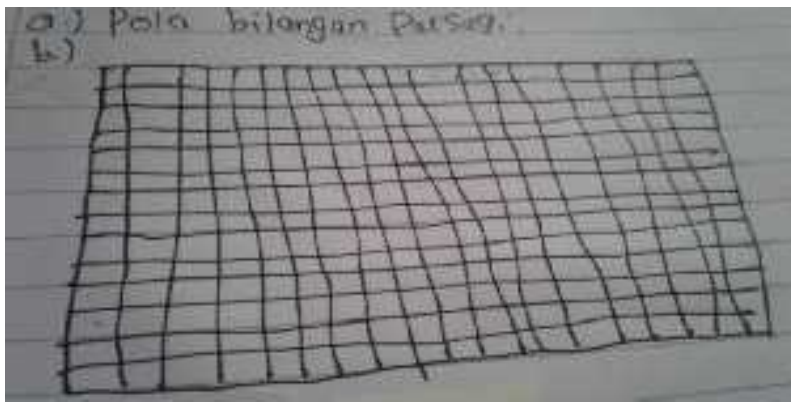

Gambar 3. Jawaban siswa kelas kontrol pada soal nomor 2

Berdasarkan hasil jawaban
diatas, terlihat bahwa pada
eksperimen selas
menyelesaikan soal pola bilangan dan

membuat gambar pola tersebut dengan baik. Sedangkan pada kelas kontrol siswa belum mampu menyelesaikan soal pola 
bilangan dan membuat gambar pola tersebut dengan baik.

2) Menggunakan dan memanfaatkan serta memilih serta memilih prosedur atau evaluasi tertentu.

Kemampuan menggunakan dan memanfaatkan serta memilih prosedur atau evaluasi tertentu pada kelas sampel ditinjau dari hasil tes kemampuan pemahaman konsep siswa pada soal nomor 3 dan 4 . Pada soal nomor 3, peneliti menyajikan suatu barisan bilangan, dan siswa diminta untuk menentukan suku ke-20 dari barisan bilangan tersebut. Jawaban siswa pada kelas eksperimen dan kontrol dapat dilihat pada gambar 4 dan gambar 5 dibawah ini.

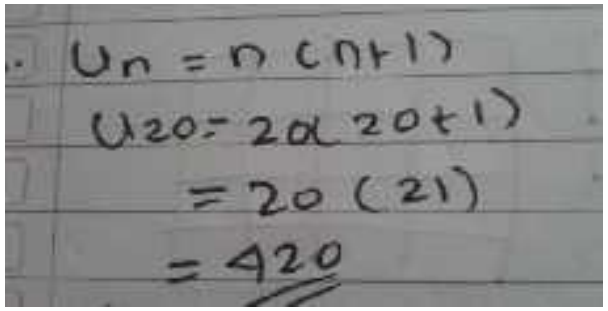

Gambar 4. Jawaban siswa kelas eksperimen pada soal nomor 3

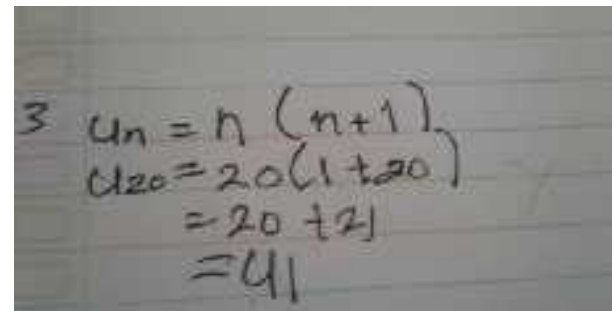

Gambar 5. Jawaban siswa kelas kontrol pada soal nomor 3

Berdasarkan hasil jawaban siswa tersebut, terlihat bahwa pada kelas eksperimen sudah mampu menggunakan dan memilih prosedur/operasi tertentu dalam menyelesaikan permasalah dengan baik. Sedangkan pada kelas kontrol siswa belum mampu menggunakan dan memilih prosedur/operasi tertentu dalam menyelesaikan masalah dengan baik.

Pada soal nomor 4, siswa diberikan gambar yang menunjukkan barisan bilangan, kemudian siswa diminta untuk menentukan banyak gambar pada pola ke-8 dan ke 22 . Jawaban dari soal no.4 tersebut pada kelas sampel, diambil dari perwakilan siswa pada kelas eksperimen dan kontrol. Berikut jawaban siswa kelas eksperimen dan jawaban siswa kelas kontrol untuk soal diatas.

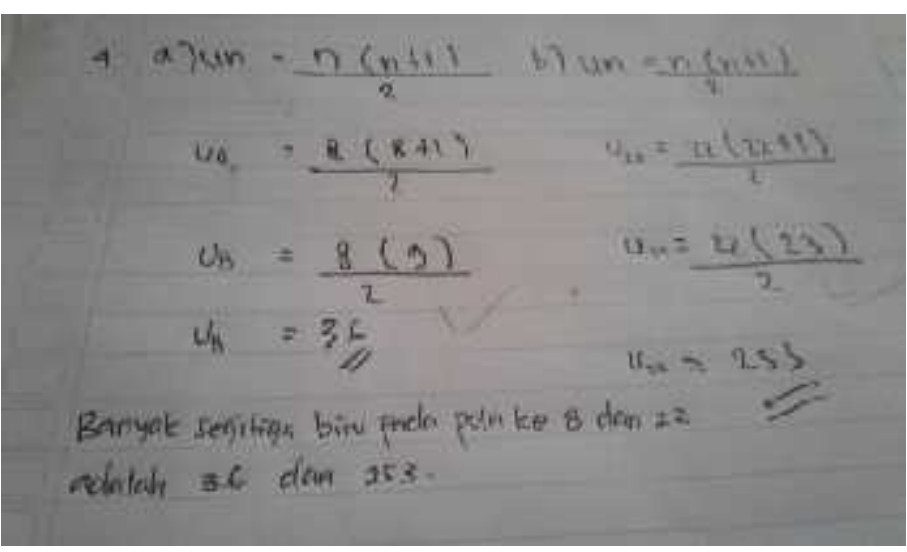

Gambar 6. Lembar Jawaban siswa kelas eksperimen pada soal nomor 4 


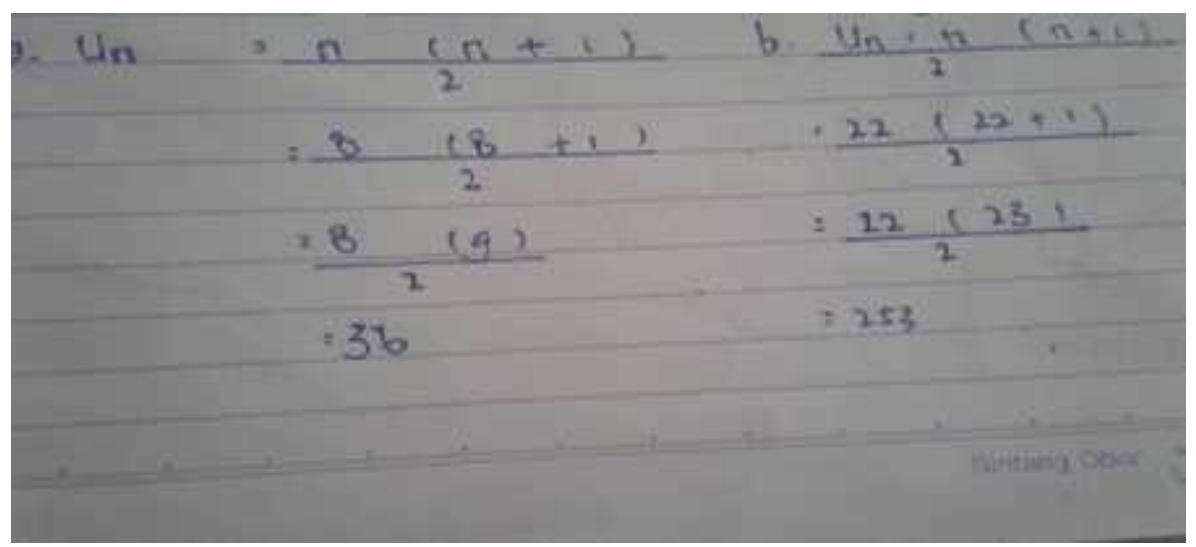

Gambar 7. Lembar Jawaban siswa kelas kontrol pada soal nomor 4

Berdasarkan hasil jawaban siswa, terlihat bahwa pada kelas eksperimen sudah mampu menggunakan dan memilih prosedur/operasi tertentu dalam menyelesaikan permasalah dengan baik dan dapat membuat kesimpulan. Sedangkan pada kelas kontrol siswa sudah mampu menggunakan dan memilih prosedur/operasi tertentu dalam menyelesaikan permasalah dengan baik hanya saja masih terdapat sedikit kesalahan dan belum bisa membuat kesimpulan.
3) Mengaplikasikan konsep atau alogaritma pada pemecahan masalah.

Kemampuan mengaplikasikan konsep atau alogaritma pada pemecahan masalah kelas sampel ditinjau dari hasil tes kemampuan pemahaman konsep matematika siswa pada soal nomor 1 . Pada soal nomor 1 , peneliti memberikan rumus suku ke-n dari suatu barisan bilangan, kemudian siswa diminta untuk menentukan hasil dari $\mathrm{U}_{7}-\mathrm{U}_{5}$. Jawaban dari soal nomor 1 tersebut pada kelas sampel, diambil dari perwakilan siswa pada kelas eksperimen dan kontrol.

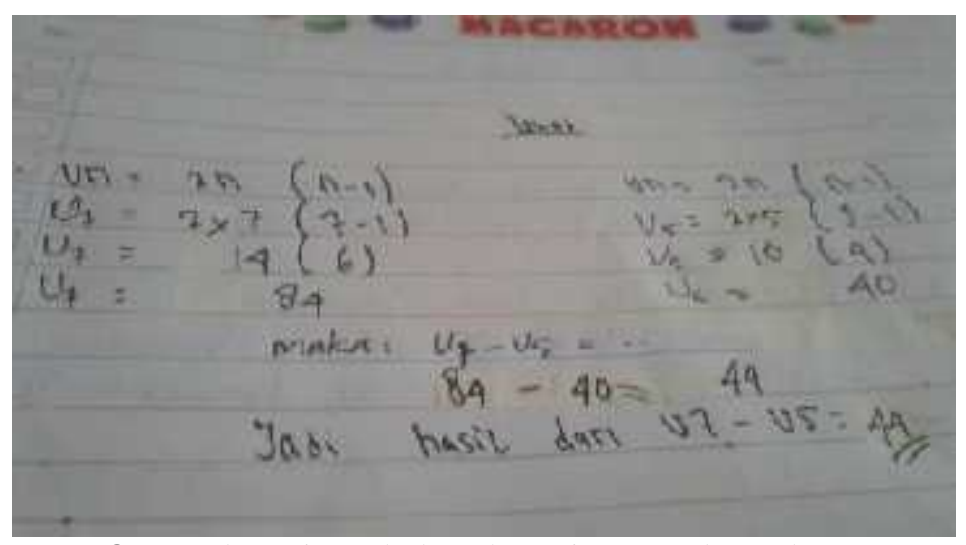

Gambar 8. Jawaban siswa kelas eksperimen pada soal nomor 1 


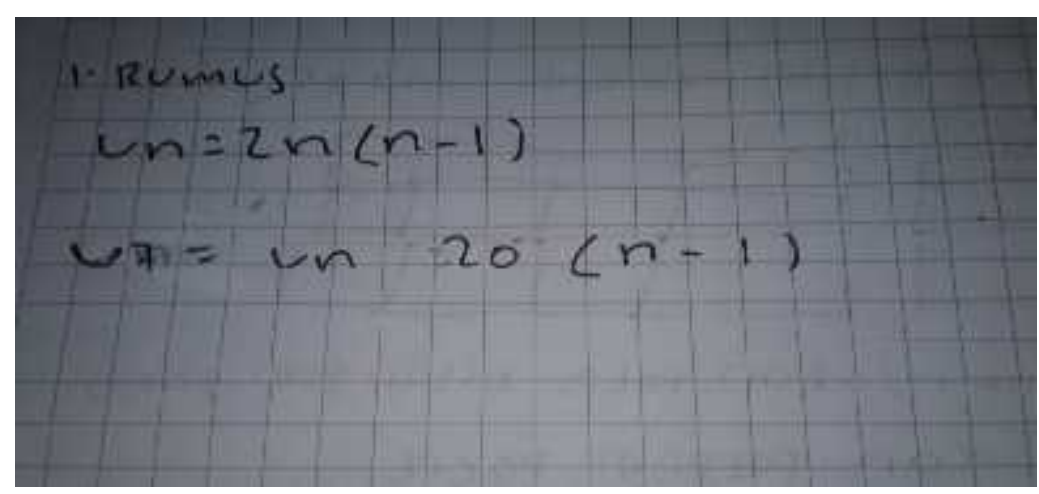

Gambar 9. Jawaban siswa kelas kontrol pada soal nomor 1

Berdasarkan hasil jawaban siswa, terlihat bahwa siswa kelas eksperimen sudah mampu mengaplikasikan konsep dan algoritma pada pemecahan masalah, dan menjawab rumus serta memberikan kesimpulan dengan baik. Sedangkan siswa kelas kontrol belum mampu mampu mengaplikasikan konsep dan algoritma pada pemecahan masalah.

\section{SIMPULAN}

Berdasarkan hasil penelitian dapat disimpulkankemampuan pemahaman konsep matematis siswa dengan menggunakan model pembelajaran Think Talk Write lebih baik daripada kemampuan pemahaman konsep matematis siswa dengan menggunakan model pembelajaran konvensional di kelas di kelas VIII MTs Al-Ihsan.

\section{REFERENSI}

Ali, H. (2014). Perencanaan dan Strategi Pembelajaran Matematika. Jakarta : PT.Raja Grafindo Persada.

Istarani. (2014). 58 Model Pembelajaran Inovatif. Medan : Media Persada.

Isrok'atun. (2018). Model-Model Pembelajaran Matematika. Jakarta : PT Bumi Aksara

Kesumawati, N. (2008). Pemahaman Konsep Matematik dalam Pembelajaran Matematika, Seminar Nasional dan Pendidikan Matematika

Shoimin, A. (2014). 68 Model Pembelajaran Inovatif dalam Kurikulum 2013. (Jakarta : AR - RUZZ MEDIA, 2014) 